\title{
Requirement of Digestible Sulfur Amino Acids in Laying Hens Fed Sorghum- and Soybean Meal-Based Diets
}

http://dx.doi.org/10.1590/1806-9061-2015-0011

-Author(s)

\section{Gomez RS',11}

Angeles ML'

National Center of Disciplinary Research in Animal Physiology, National Institute of Research in Forestry, Agriculture and Livestock, Ajuchitlán, Querétaro, México.

" Faculty of Superior Studies Cuautitlán, National Autonomous University of México, Ajuchitlán, Querétaro, México.

\section{a Mail Address}

Corresponding author e-mail address Sergio Gomez Rosales

Progreso 5. Barrio de Santa Catarina. Delegacion Coyoacan

04010. Mexico, DF, Mexico

Phone: (52) 5538718700

E-mail: checogr8@gmail.com

\section{EKeywords}

Laying hens, Requirements, Methionine, Cysteine, Productivity.

\section{ABSTRACT}

Two experiments were done to evaluate the effect of increasing levels of dietary digestible methionine (Met) and Met:cysteine (Met:Cys) ratio on the productivity of Hy-Line W-36 laying hens fed sorghum- and soybean meal-based diets. In Exp. 1, 160 hens from 68 to 75 weeks of age were assigned to four dietary levels of digestible Met $(0.20$ $0.24,0.28$ and $0.32 \%$ ). The digestible total sulfur amino acids:Lysine (TSAA:Lys) ratios were: 62, 68, 76 and 84\%. In Exp. 2, 192 hens from 76-83 weeks of age were assigned to four dietary digestible Met:Cys ratios $(160,116.7,85.7$ and $62.5 \%)$. The digestible TSAA:Lys ratio was kept constant across diets (80\%). Results were subjected to ANOVA and linear regression analyses. In Exp. 1, optimal egg production, egg mass, and feed efficiency responses were observed at 0.30 and $0.50 \%$ of dietary digestible Met and TSAA, respectively (quadratic effect, $p<0.05$ ). Live performance was maximized with digestible Met and TSAA in takes of 288 and 478 mg/hen/d, respectively. In Exp. 2, optimal egg production and feed efficiency responses were observed at 151 and $150 \%$ of dietary digestible Met:Cys ratios, respectively (quadratic effect, $p<0.05$ ). The digestible Met, Cys and TSAA intake to maximize egg production and feed efficiency were 313, 207 and $510 \mathrm{mg} / \mathrm{hen} / \mathrm{d}$, respectively. The requirements for sulfur AA in Hy-Line W-36 hens from 68 to 83 weeks of age fed sorghum- and soybean meal-based diets fell inside the range of the requirements previously estimated in hens fed corn-soybean meal based diets.

\section{INTRODUCTION}

Grain sorghum (Sorghum bicolor L. Moench) is the fifth largest cereal crop in the world after wheat, rice, corn, and barley, with an annual production in the order of 56 million metric tons (Taylor \& Shewry, 2006; Wong et al., 2009). Sorghum crops can be adapted to many different agro-ecological environments due to its rusticity, resistance to adverse weather conditions, and lower water requirements relative to corn crops. Sorghum tolerates heat and salinity better than corn, and can grow in a wide variety of soils with a limited supply of nutrients (Dendy \& Dobraszczyk, 2001; Gómez et al., 2009). Given the advantages of sorghum, its production is strategic in several parts of the world and is one of the best animal feeding alternatives in places where other crops have poorer yields or their production is not feasible. Furthermore, due to the declining global grain stocks due to global warming, it is expected that in the near future heat resistant crops such as sorghum are routinely utilized as food and feed resources for humans and animals (Selle et al., 2010; García et al., 2013).

Considering the above scenario, significant amounts of sorghum can be locally available at very competitive prices compared with 
other cereals, and its inclusion in animal diets may be economically attractive. In addition, the use of locallyproduced sorghum could reduce the dependence on imported cereals in countries where the production of other cereal grains is limited. However, sorghumbased diets have been associated with inconsistent, and even sub-optimal growth performance of broiler chickens. Sorghum is unique in that it contains kafirin, phytate, and may contain condensed tannin; these factors can negatively influence the nutritive properties of sorghum (Selle et al., 2010; García et al., 2013).

In experiments with pigs fed different low- and high-tannin containing sorghum varieties (MariscalLandín et al., 2004; Mariscal-Landín et al., 2010), low or very low ileal standardized digestibility values of arginine (Arg), histidine (His), and proline (Pro), and the lowest lysine ileal standardized digestibility were determined in high-tannin sorghum compared to the remaining sorghum varieties. The use of improved sorghum varieties with low levels of antinutritional factors may partially alleviate the problems associated with the poor quality of sorghum. Ramírez et al. (2005) conducted a study in Mexico with 216 sorghum samples and found PC and tannin concentration ranges of 5.2 to 11.0 and 0.02 to $5.06 \%$, respectively. Tannins were the most variable component with a coefficient of variation of $152.8 \%$. It was also reported that $91.7 \%$ of the samples had tannin levels below $1.5 \%$ and only $1.86 \%$ of the samples contained tannin values higher than 3.9\%. These results suggest that the probability of the inclusion of high-tannin sorghum varieties in poultry diets is low.

Furthermore, the application of the ideal $A A$ profile concept to set the AA requirements in animals is expected to derive in better and more reliable estimates of the AA requirements (Rostagno et al. 2005), which can be applied to poultry reared under different production conditions (Angeles \& Gómez, 2005; Gomez \& Angeles, 2009). An advantage of using the ideal AA concept is the possibility to substitute conventional for non-conventional feed ingredients with different nutritional quality, such as the substitution of corn by sorghum as a source of energy and AA. For instance, it was shown that the digestible Lys, Met and Thr requirements of laying chickens fed sorghumand soybean meal-based diets formulated according to the ideal $A A$ profile were within the range of the requirements of the same $A A$ established in laying hens fed corn-soybean meal based diets (Angeles \& Gómez, 2005; Gomez \& Angeles, 2009).

Methionine is the first limiting AA in hens fed corn- or sorghum- and soybean meal-based diets (Cortes et al., 2001; Novak et al., 2006; Saki et al., 2012). An important aspect of the Met requirement is that this AA and Cys contain sulfur in their structure, and within the body, under conditions of deficiency of Cys, Met can be used to synthesize one molecule of Cys. This can lead to a deficiency of Met, which must be supplied in the diet because it cannot be synthesized by animal tissues. Therefore, in poultry diet formulation, in addition of supplying Met and Cys requirements, it is important to supply the exact amounts and ideal profile of total sulfur AA (TSAA) needed for optimal production. Such concepts should be considered, particularly when diets are based on sorghum, which contains levels of digestible sulfur amino acids compared to corn, which may cause marginal Met, Cys, or TSAA deficiencies. Therefore, the objective of this study was to evaluate the effect of increasing Met levels and Met:Cys ratios on the productivity of Hy-Line W-36 laying hens fed sorghum- and soybean meal-based diets.

\section{MATERIALS AND METHODS}

The experiments were carried out in the facilities of the Experimental Poultry Unit of the National Center of Disciplinary Research in Animal Physiology (CENIDFyMA-INIFAP), located in Querétaro, México. The experimental procedures were revised and approved by the Ethical Committee of Animal Use of the CENIDFyMA-INIFAP.

\section{Experiment 1}

One hundred and sixty Hy-Line W-36 hens were evaluated from 68 to 75 weeks of age and fed sorghum- and soybean meal-based diets with four levels of digestible Met $(0.20,0.24,0.28$, and $0.32 \%)$. The amino acid profiles of sorghum and soybean meal were calculated using prediction equations based on the analyzed protein composition and on the digestibility coefficients estimated from the table published by Mariscal et al. (1998). A basal diet was formulated to contain $12.4 \% \mathrm{CP}, 2840 \mathrm{kcal} \mathrm{ME} / \mathrm{kg}$ of feed, $0.20 \%$ digestible Met and $0.20 \%$ digestible Cys (Table 1). The limiting AA Lys, Thr and lle were added from crystalline sources to meet or exceed the optimum ratio of essential $A A$. 
Table 1 - Ingredients and nutritional composition of the experimental diets (as-fed basis).

\begin{tabular}{|c|c|c|c|}
\hline Ingredients & $\%$ & Nutrient & Content \\
\hline Ground sorghum & 62.67 & $\mathrm{ME}, \mathrm{kcal} / \mathrm{kg}$ & 2840 \\
\hline Soybean meal & 20.74 & $C P, \%^{b}$ & 12.8 \\
\hline Calcium carbonate & 10.0 & Calcium, \% & 4.0 \\
\hline Calcium phosphate & 1.45 & Available P, \% & 0.32 \\
\hline Soybean oil & 4.10 & & \\
\hline Salt & 0.39 & Amino acids ${ }^{c}$ & \\
\hline Premix ${ }^{a}$ & 0.20 & Lysine & $0.65(100)$ \\
\hline Sodium bicarbonate & 0.07 & Methionine & $0.20(31)$ \\
\hline Antioxidant & 0.02 & Cysteine & $0.20(31)$ \\
\hline L-Lysine & 0.13 & Met + Cys & $0.40(62)$ \\
\hline L-Threonine & 0.07 & Threonine & $0.45(69)$ \\
\hline \multirow[t]{4}{*}{ L-Isoleucine } & 0.16 & Tryptophan & $0.16(25)$ \\
\hline & & Isoleucine & $0.58(89)$ \\
\hline & & Valine & $0.65(100)$ \\
\hline & & Arginine & $0.84(129)$ \\
\hline
\end{tabular}

a Each kg provided: vitamin A, 7,700 IU; vitamin $D_{3}, 3,000 \mathrm{IU}$; vitamin E, $6.6 \mathrm{IU}$; vitamin K, 2.0 mg; riboflavin, 4.4 mg; niacin, 22 mg; pantothenic acid 5.5 mg; choline, 300 mg; folic acid, 0.11 g; vitamin $B_{12}, 8.8 \mathrm{mg}$; manganese, $100 \mathrm{mg} ;$ zinc, $100 \mathrm{mg}$; iron, $33 \mathrm{mg}$; copper, $9 \mathrm{mg}$; iodine, $0.9 \mathrm{mg}$; selenium, $0.3 \mathrm{mg}$. ${ }^{\mathrm{b}}$ Analyzed. ' Amino acids are given on digestible basis. The amino acid ratios to Lys are shown between parentheses.

The basal diet was mixed and divided into four equal portions, to which four increasing levels of DL-Met were added $(0.0,0.04,0.08$, and $0.12 \%)$ to achieve the desired dietary Met levels. The dietary digestible TSAA concentrations were $0.40,0.44,0.48$, and $0.52 \%$ and the TSAA:Lys ratios were $62,68,76$, and $84 \%$, as the digestible Met levels increased in the basal diet.

\section{Experiment 2}

One hundred ninety two Hy-Line W-36 hens, between 76 and 83 weeks of age (from a different group of those used in the first experiment) were fed sorghum- and soybean meal-based diets with four digestible Met:Cys ratios (160, 116.7, 85.7, and $62.5 \%)$. The basal diet was similar to that used in Experiment 1, but in Experiment 2, dietary digestible TSAA level was kept constant across all diets (80\%). To accomplish this, the basal diet was also mixed and then divided in four portions to which the crystalline Met and Cys were added to obtain the proper Met:Cys ratios. Met and Cys were adjusted in $0.04 \%$ units as follows: $(0.32: 0.20,0.28: 0.24,0.24: 0.28$ and 0.20:0.32\%).

\section{General procedures}

There were 10 and 12 replicates per treatment in Experiment 1 and 2, respectively. Each replicate consisted of two adjacent cages with two hens per cage for a total of four hens in each replicate. In both experiments hens were kept on treatments for eight weeks; the first two weeks were considered as adaptation period, and for the statistical analysis only data from weeks 3-8 were included.

Hens were housed in battery cages equipped with trough feeders and bowl drinkers. Feed allowance was restricted to $95 \mathrm{~g}$ of feed/hen/d in both experiments to prevent AA over feeding. This was considered a minor feed restriction since the normal feed intake expected in hens from 65 to 80 weeks of age is on average 96 $\mathrm{g}$ of feed/hen/d (Hy-Line Management Guide, 2011). Body weight was recorded at the beginning and end of each experiment, egg production was daily recorded, and all eggs were weekly weighed. The change in body weight was estimated by the difference between the initial and final weight. Egg mass was estimated by multiplying egg production percentage by egg weight, and the feed efficiency was estimated by dividing the egg mass over feed intake.

\section{Statistical analysis}

Data were subjected to analysis of variance (ANOVA) using the general linear models procedures of SAS software (1990) according to a randomized block design (Steel \& Torrie, 1980). In all analyses, percentage data were transformed to arsine data before analysis. Least square means are shown in Tables 1 and 2 . Variables that were affected by dietary Met level or Met:Cys ratios were submitted to linear and non-linear regression analyses. Results from both experiments were best fitted using polynomial (quadratic response) regression analysis of the data. Based on the quadratic equation developed, the dietary requirements of Met (Experiment 1) and Met:Cys ratios (Experiment 2) were estimated as the curve inflection point from the analyses of the first derivative. The Met levels and Met:Cys ratios required to achieve maximal responses were obtained by dividing the derivative of the responses by the derivative of Met and Met:Cys ratios.

\section{RESULTS}

\section{Experiment 1}

The means of the live performance responses observed in Experiment 1 are shown in Table 2. The results indicate a quadratic response $(p<0.05)$ of egg production $\left(y=-14.975+658.13 x-1109.4 x^{2} ; R^{2}=\right.$ 0.95), egg mass $\left(y=-45.87+584.5 x-937.5 x^{2} ; R^{2}\right.$ $=0.98)$, and feed efficiency ( $y=-0.4828+6.1526 x$ $\left.-9.8684 x^{2} ; R^{2}=0.98\right)$ to increasing dietary digestible Met levels. Using these equations, the curve inflection point from the analysis of the first derivative show maximum responses of $0.30,0.31$ and $0.30 \%$ dietary 
digestible Met levels for egg production, egg mass, and feed efficiency, respectively (Table 4). Egg weight showed a positive linear response $(p<0.05)$ to dietary digestible Met level $\left(y=88.5 x+27.84 ; R^{2}=0.91\right)$. Dietary Met level did not affect body weight.

Table 2 - Performance parameters of laying hens fed increasing levels of dietary methionine (Exp. 1)

\begin{tabular}{|c|c|c|c|c|c|}
\hline \multirow[b]{2}{*}{ Variable response } & \multicolumn{4}{|c|}{ Level of dietary Met, \% } & \multirow[b]{2}{*}{ SEM ${ }^{\circ}$} \\
\hline & 0.20 & 0.24 & 0.28 & 0.32 & \\
\hline Feed intake, $\mathrm{g}$ & 95.0 & 95.0 & 95.0 & 95.0 & --- \\
\hline Digestible Met intake, mg/d & 190 & 228 & 266 & 304 & --- \\
\hline Digestible TSAA intake, mg/d & 380 & 418 & 456 & 494 & --- \\
\hline Egg production, $\%$ b & 72.7 & 77.8 & 83.6 & 81.6 & 2.006 \\
\hline Egg weight, $g^{c}$ & 44.2 & 50.6 & 53.6 & 55.0 & 1.068 \\
\hline Egg mass, $g^{b}$ & 33.8 & 39.6 & 45.1 & 44.9 & 1.491 \\
\hline Feed efficiency ${ }^{b}$ & 0.36 & 0.42 & 0.47 & 0.47 & 0.016 \\
\hline Body weight change, $g$ & -8.3 & -28.9 & -26.7 & -17.4 & 0.030 \\
\hline
\end{tabular}

${ }^{a}$ SEM $=$ Standard error of the mean. ${ }^{b}$ Quadratic effect, $p<0.05 .{ }^{c}$ Linear effect, $p<0.05$.

\section{Experiment 2}

The performance results obtained in Experiment 2 (Table 3) indicate that egg production $(y=35.022$ $\left.+0.5451 x-0.0018 x^{2} ; R^{2}=0.99\right)$, feed efficiency ( $y$ $\left.=0.3182+0.003 x-0.00001 x^{2} ; R^{2}=0.99\right)$, and body weight change $\left(y=-86.812+1.1092 x-0.0045 x^{2}\right.$; $\left.R^{2}=0.87\right)$ presented a quadratic response $(p<0.05)$ when dietary digestible Met:Cys ratio was reduced from 160 to $62.5 \%$. Using these equations, the curve inflection point from the analysis of the first derivative show maximum egg production and feed efficiency responses and minimum body weight loss with 151, 150 , and $123 \%$ of dietary Met:Cys ratio, respectively (Table 4). Egg mass linearly decreased $(p<0.05)$ with the reduction of Met:Cys ratios ( $y=36.952+0.0894 x$; $\left.R^{2}=0.94\right)$, but egg weight was not affected by dietary Met:Cys ratios.

Table 3 - Performance parameters of laying hens fed increasing dietary methionine:cysteine ratios (Exp. 2)

\begin{tabular}{|c|c|c|c|c|c|}
\hline \multirow[b]{2}{*}{ Response variables } & \multicolumn{4}{|c|}{ Methionine:Cysteine ratio, \% } & \multirow[b]{2}{*}{ SEM $^{a}$} \\
\hline & 160.0 & 116.7 & 85.7 & 62.5 & \\
\hline Feed intake, $\mathrm{g}$ & 95.0 & 95.0 & 95.0 & 95.0 & --- \\
\hline $\begin{array}{l}\text { Digestible Met intake, } \\
\mathrm{mg} / \mathrm{d}\end{array}$ & 304 & 266 & 228 & 190 & --- \\
\hline $\begin{array}{l}\text { Digestible Cys intake, } \\
\mathrm{mg} / \mathrm{d}\end{array}$ & 190 & 228 & 266 & 304 & --- \\
\hline Egg production, \% ${ }^{b}$ & 76.3 & 75.2 & 68.3 & 62.5 & 2.088 \\
\hline Egg weight, g & 65.1 & 65.1 & 65.2 & 64.8 & 0.590 \\
\hline Egg mass, $g^{c}$ & 49.5 & 48.8 & 44.5 & 42.0 & 1.635 \\
\hline Feed efficiency ${ }^{b}$ & 0.55 & 0.54 & 0.50 & 0.47 & 0.018 \\
\hline Body weight change, $\mathrm{g}^{\mathrm{b}}$ & -25.0 & -21.7 & -21.7 & -36.7 & 0.009 \\
\hline
\end{tabular}

${ }^{a} \mathrm{SEM}=$ Standard error of the mean. ${ }^{\mathrm{b}}$ Quadratic effect, $\mathrm{p}<0.05 .{ }^{\mathrm{c}}$ Linear effect, $\mathrm{p}<0.05$.

\section{DISCUSSION}

In the present study, it was assumed that $A A$ requirements for egg production were the same, regardless of the age of the hens. The NRC (1994) recommends a single requirement for each $A A$ during the first and the second cycles of egg production, given that the changes in $\mathrm{AA}$ requirements are regulated by changes in the level of feed intake of the hens. This argument is questionable since the level of feed intake may widely vary among flocks, and in many cases, laying hens can consume more feed than that required to support egg production. In the present study, in order to prevent significant differences in feed intake, and consequently in AA intake, the daily feed allowance was fixed in both experiments reported here.

In Experiment 1, based on the estimated optimal dietary digestible Met and TSAA requirements for egg production and feed efficiency (0.30 and 0.50\%) and for egg weight (0.31 and $0.51 \%$ ) and on feed intake $(95 \mathrm{~g} / \mathrm{d})$, the digestible Met and TSAA intake for maximum egg production, egg mass, and feed efficiency were calculated as 282, 296, and $287 \mathrm{mg} /$ hen/d, and 472, 486, and $477 \mathrm{mg} / \mathrm{hen} / \mathrm{d}$, respectively. On average, the digestible Met and TSAA intake to maximize the productive performance were 288 and $478 \mathrm{mg} / \mathrm{hen} / \mathrm{d}$, respectively.

According to the AA recommendations of the NRC (1994), white-egg layers consuming $100 \mathrm{~g}$ of feed/d during the first laying cycle have a requirement of 258 and $499 \mathrm{mg}$ of digestible Met and TSAA/hen/d, respectively. In a recent study, Saki et al. (2012) reported that white commercial laying hens fed a cornwheat-soybean meal diet from 22 to 36 weeks of age presented digestible Met and TSAA/hen/d requirements of 229 and $438 \mathrm{mg}$, respectively. The Met requirement estimated in the present study was higher than that reported by the NRC (1994) and by Saki et al. (2012). On the other hand, the TSAA requirement estimated in the present study was lower than the NRC (1994) and higher compared to that of Saki et al. (2012).

Our estimated Met intake is also in close agreement to the requirements reported by Coon \& Zhang (1998) of $283 \mathrm{mg} / \mathrm{hen} / \mathrm{d}$, but the TSAA is lower than the value of $496 \mathrm{mg} / \mathrm{hen} / \mathrm{d}$ observed in Hy-Line W36 hens fed corn-soybean meal based diets from 60-72 weeks of age. In the same report of Coon \& Zhang (1998), but for Dekalb XL layer hens fed corn-soybean meal based diets from 29 to 41 weeks of age, the digestible Met and TSAA requirements were 352 and 596 $\mathrm{mg} / \mathrm{d}$, respectively. In a previous research by the same 
Table 4 - Quadratic equations, inflection point and intake of digestible methionine, cysteine and total sulfur amino acids in Exp. 1 and Exp. 2

\begin{tabular}{|c|c|c|c|c|c|c|}
\hline \multirow[b]{2}{*}{ Item } & \multirow[b]{2}{*}{ Regression equation } & \multirow[b]{2}{*}{$R^{2}$} & \multirow[b]{2}{*}{ Inflection point } & \multicolumn{3}{|c|}{ Intake, mg/hen/d ${ }^{c}$} \\
\hline & & & & Met & Cys & TSAA \\
\hline \multicolumn{7}{|l|}{ Experiment $1^{\mathrm{a}}$} \\
\hline Egg production, \% & $y=-14.975+658.13 x-1109.4 x^{2}$ & 0.95 & 0.30 & 282 & 200 & 472 \\
\hline Egg mass, g & $y=-45.87+584.5 x-937.5 x^{2}$ & 0.98 & 0.31 & 296 & 200 & 486 \\
\hline Feed efficiency & $y=-0.4828+6.1526 x-9.8684 x^{2}$ & 0.98 & 0.30 & 287 & 200 & 477 \\
\hline \multicolumn{7}{|l|}{ Experiment $2^{\mathrm{b}}$} \\
\hline Egg production, \% & $y=35.022+0.5451 x-0.0018 x^{2}$ & 0.99 & 151 & 314 & 206 & 510 \\
\hline Feed efficiency & $y=0.3182+0.003 x-0.00001 x^{2}$ & 0.99 & 150 & 312 & 208 & 510 \\
\hline Body weight change, $\mathrm{g}$ & $y=-86.812+1.1092 x-0.0045 x^{2}$ & 0.87 & 123 & 287 & 233 & 510 \\
\hline \multicolumn{7}{|c|}{ a Quadratic effect of dietary digestible Met level, $p<0.05$. } \\
\hline \multicolumn{7}{|c|}{ b Quadratic effect of dietary digestible Met:Cys ratios, $p<0.05$. } \\
\hline
\end{tabular}

laboratory, requirements of 350 and $595 \mathrm{mg}$ digestible Met and TSAA were estimated (Cao et al., 1995). In these last two reports, the reported Met and TSAA requirement values were higher than those estimated in our research.

In other studies published during the last decade, reported Met and TSAA requirements were higher compared with the estimations of the present research. Bunchasak \& Silapasorn (2005) reported a requirement of $420 \mathrm{mg}$ digestible Met for maximum egg production in Isa-brown laying hens from 24-44 weeks of age. Polese et al. (2012) reported a requirement of 682 $\mathrm{mg}$ of digestible TSAA/hen/d in brown egg laying hens from 50 to 66 weeks of age. Filho et al. (2006) estimated a requirement of $697 \mathrm{mg}$ digestible TSAA hen/d for semi-heavy laying hens from the beginning to the peak of egg production. In the last three reports hens were fed corn-soybean meal based diets.

In laying hens fed sorghum- and soybean mealbased diets, digestible Met requirements of 313 and $343 \mathrm{mg} / \mathrm{hen} / \mathrm{d}$ were reported for maximum egg production and egg weight for 100- to 108-week-old layers (Gomez \& Angeles, 2009). Also, a digestible TSAA requirement of $553 \mathrm{mg}$ was estimated fro IsaBabcock B300 hens fed sorghum- and soybean mealbased diets from 24 to 34 weeks of age by Fuente et al. (2005).

The above observations indicate that in previous research, laying hens fed corn-based diets showed either lower (NRC, 1994; Saki etal., 2012), similar (Coon \& Zhang, 1998; Hy-Line W36 hens) or greater (Coon \& Zhang, 1998 [using Dekalb XL laying hens]; Bunchasak \& Silapasorn, 2005) digestible Met requirements compared with the layers in the present research, which were fed sorghum-based diets. Furthermore, Gomez \& Angeles (2009) reported higher digestible Met requirement in layers fed sorghum-based diets compared with the present study. Regarding TSAA requirements, our estimates are higher only than that reported by Saki et al. (2012), but are lower compared to the remaining reports (NRC, 1994; Coon \& Zhang, 1998; Filho et al., 2006; Polese et al., 2012), including one in which hens were also fed sorghum-based diets (Fuente et al., 2005).

The findings of the present report were also compared with two recent meta-analyses based on literature reviews. In the review of Joly (2010), the results of 15 experiments published between 1990 and 2005 indicated that the digestible Met and TSAA requirements were 420 and $650 \mathrm{mg} / \mathrm{hen} / \mathrm{d}$, respectively. Furthermore, in the meta-analysis performed by Lemme (2009) of 19 experiments published between 1990 and 2006, digestible Met and TSAA requirements of 415 and 777 mg/hen/d, respectively, were estimated. It should be noted that the estimated values in both reviews are also higher than the values of the present research.

It may be argued that the estimated digestible Met and TSAA requirements reported here may have been lower because of the lower egg mass shown by the older hens used in the present study (Table 2 and 3). This argument could be clarified by expressing the daily digestible Met and TSAA requirements per gram of egg content. The estimated maximum egg mass (45.0 g) observed in the present report was multiplied by 0.911 (Coon \& Zhang, 1998) and then divided by the average intake of digestible Met and TSAA (288 and $478 \mathrm{mg} / \mathrm{hen} / \mathrm{d}$, respectively). On this basis, the daily 
Met and TSAA required per gram of egg content were 6.96 and $11.60 \mathrm{mg}$. Coon \& Zhang (1998) reported requirements of $7.04 \mathrm{mg}$ Met and $10.96 \mathrm{mg}$ TSAA per gram of egg content in Hy-Line W36 hens with 60-72 weeks of age producing $50 \mathrm{~g}$ of egg mass $\mathrm{d}^{-1}$. Also, in a previous study, Cao et al. (1995) reported digestible Met and TSAA requirements of 6.48 and $11.02 \mathrm{mg}$ per gram of egg content in hens producing $54 \mathrm{~g}$ of egg mass $\mathrm{d}^{-1}$. In laying hens in the second cycle of lay, Gomez \& Angeles (2009) obtained a Met requirement of $7.02 \mathrm{mg}$ per gram of egg content. In the literature review of Joly (2010), digestible Met requirement was estimated as $7.11 \mathrm{mg}$ per gram of egg content. The results of Fuente et al. (2005) indicate a digestible TSAA requirement of $12.14 \mathrm{mg}$ per gram of egg content. The estimated Met and TSAA requirements per gram of egg content in the present research were within the range of the values previously reported.

The estimated digestible Lys content of the basal diet was $0.65 \%$ and the estimated digestible Lys intake was $617.5 \mathrm{mg} / \mathrm{hen} / \mathrm{d}$. Therefore, the average Met:Lys and the TSAA:Lys ratio were 47 and $77 \%$, respectively.

The estimated Met:Lys ratio is higher than the ratios of 43 and $44 \%$ recommended by the NRC (1994) and Jais et al. (1995), respectively, similar to the $47 \%$ ratio reported by Bregendhal et al. (2008), and slightly lower than the $49 \%$ ratio obtained by Coon \& Zhang (1998) and the 50\% ratio determined by the CVB (1996) and Rostagno et al. (2005).

Furthermore, the observed TSAA:Lys ratio is consistent with the $81 \%$ ratio recommended by Coon \& Zhang (1998), but it is slightly lower than the $84 \%$ ratio of the NRC (1994) and far lower than other ratios, of $91-94 \%$ reported by other sources (CVB, 1996; Rostagno et al., 2005; Bregendhal et al., 2008).

Egg weight presented a positive linear response to increasing dietary Met levels. This response is supported by a previous report (Gomez \& Angeles, 2009) and is consistent with earlier results indicating that the dietary Met level required to achieve maximum egg weight is higher than that required for maximum egg production (Shafer et al., 1996; Shafer et al., 1998; Narvaez-Solarte et al., 2005). The same pattern was observed in other studies in which TSAA requirements were estimated (Filho et al., 2006; Polese et al., 2012).

In Experiment 2, the greater egg production and feed efficiency and lower weight loss obtained at the higher Met:Cys ratios emphasizes the essentiality of Met over Cys. Based on the estimated optimum Met:Cys ratios for egg production (152\%), feed efficiency $(150 \%)$, and body weight change (123\%), as well on feed intake results $(95 \mathrm{~g} / \mathrm{d}$ ), the digestible Met and Cys intake for maximum egg production and feed efficiency and to reduce body weight loss were calculated as 314 and 206, 312 and 208 and 287 and $233 \mathrm{mg} / \mathrm{hen} / \mathrm{d}$, respectively. In all cases, the digestible TSAA intake was $510 \mathrm{mg} / \mathrm{hen} / \mathrm{d}$.

On average, the digestible Met and Cys intake to maximize the egg production and feed efficiency were 313 and 207 mg/hen/d, respectively. These values are higher than the estimated digestible Met and Cys intake of 288 and 200 mg/hen/d observed in Experiment 1. The main reason for these differences may be that the higher average egg weight obtained in Experiment 2 compared to Experiment 1. However, the estimated digestible Met in Experiment 2 is considered normal because it is within the range of the values already presented in the discussion of Experiment 1. This comment also applies to the digestible TSAA intake (510 mg/hen/d) observed in Experiment 2.

The basal diet used in Experiment 1 and 2 provided a minimum of $200 \mathrm{mg}$ digestible Cys. Results from Experiment 2, in which synthetic Cys was supplemented to the basal diet, indicate that only a small extra amount (7 mg/hen/d) of Cys may be needed for maximum egg production and feed efficiency. On the other hand, for maximum egg mass, no extra Cys was required since this response was linearly depressed as Cys addition to the basal diet increased. This result resembles a previous report of Harms \& Russell (1996), who stated that a corn-soybean meal diet would always supply more Cys than required by the commercial laying hen. This seems to hold true also for sorghum- and soybean meal-based diets.

A wide variation in Met:Cys ratios (from 107 to $183 \%$ ) and Cys requirements (from 197 to 362 mg/ hen/d) can be found in the previously cited literature (Coon \& Zhang, 1998; NRC, 1994; Joly, 2010; Lemme, 2009). For instance, the tables of requirements published by the NRC (1994) suggest a Met:Cys ratio and digestible Cys requirement of $107 \%$ and $241 \mathrm{mg} /$ hen/d, respectively. From the analysis of published articles, Joly (2010) reported a Met:Cys ratio of $182 \%$ and a Cys requirement of $230 \mathrm{mg} / \mathrm{hen} / \mathrm{d}$, whereas Lemme (2009) estimated a Met:Cys ratio and Cys requirement of $115 \%$ and $362 \mathrm{mg} / \mathrm{hen} / \mathrm{d}$. In the experiment of Coon \& Zhang (1998) with 33-week-old Hy-Line W36 hens, a Met:Cys ratio of $180 \%$ and a Cys requirement of $197 \mathrm{mg} / \mathrm{hen} / \mathrm{d}$ were reported. These results suggest that there is not a defined relationship between the Met:Cys ratio and the Cys requirement. The same conclusion was drawn from the literature reviews reported by Joly (2010) and Lemme (2009). 
In Experiment 2, differently from Experiment 1, egg weight was not affected by Met:Cys ratio changes, possibly because in Experiment 2 the dietary TSAA was kept constant across all treatments (80\%), while in Experiment 1, this ratio was increased from $62 \%$ in the basal diet to $84 \%$ in the diet with the highest Met addition.

In a previous experiment (Gomez \& Angeles, 2009), Hy-Line W-36 hens between 100 and 108 weeks of age (in the second egg-production cycle) fed sorghum-soybean meal diets showed similar Met and Thr requirements compared to hens on the first cycle of egg production fed corn-soybean meal diets. Also, Hy-Line W-36 hens between 60-70 weeks of age fed sorghum-soybean meal diets presented similar Lys requirement as younger hens fed cornsoybean meal diets (Angeles \& Gómez, 2005). These previous reports, in addition to the results observed in the present research, suggest that laying hens fed sorghum-based diets have the same AA requirements as hens fed corn-based diets.

It is concluded that for Hy-Line W-36 hens between 68 and 75 weeks of age (Experiment 1), optimum egg production, egg mass, and feed efficiency were obtained with 0.30 and $0.50 \%$ of dietary digestible Met and TSAA, respectively. The productive performance was maximized at digestible Met and TSAA intakes of 288 and $478 \mathrm{mg} / \mathrm{hen} / \mathrm{d}$, respectively, and at Met:Lys and TSAA:Lys ratios of 47 and $77 \%$, respectively. Also, in Hy-Line W-36 hens between 76-83 weeks of age (Experiment 2), optimum egg production and feed efficiency responses and the least body weight loss were observed at 151, 150, and 123\% of dietary Met:Cys ratio, respectively. Digestible Met, Cys, and TSAA intake to maximize egg production and feed efficiency were 313, 207 and $510 \mathrm{mg} / \mathrm{hen} / \mathrm{d}$, respectively. These data suggest that Met, Cys and TSAA requirements of layers between 68 and 83 weeks of age fed sorghumand soybean meal-based diets obtained in the present study are within the range of the values established in younger layers in the first egg production cycle and fed corn-soybean meal based diets.

\section{REFERENCES}

Angeles ML,Gómez S. Efecto del nivel de lisina digestible y del perfil ideal de aminoácidos sobre el requerimiento de lisina en gallinas $\mathrm{Hy}-$ Line W-36 al final del primer periodo de postura. Veterinaria México 2005;36:279-294

Bregendahl K, Roberts SA, Kerr B, Hoehler D. Ideal ratios of isoleucine, methionine, methionine plus cysteine, threonine, tryptophan and valine relative to lysine for white Leghorn-type laying hens of twentyeight to thirty-four weeks of age. Poultry Science 2008;87:744-758.
Bunchasak C, Silapasorn T. Effects of adding methionine in low-protein diet on production performance, reproductive organs and chemical liver composition of laying hens under tropical conditions. International Journal of Poultry Science 2005;4:301-308.

Cao Z, Cai H, Coon C. Methionine and cystine requirements and metabolism for layers and broilers. Proceedings of 56th Minesota Nutrition Conference; 1995; Bloomington, Minesota. USA; 1995. p.257-289.

Coon C, Zhang B. Ideal amino acid profile and metabolizable energy requirement for layers. Proceedings of 59th Minnesota Nutrition Conference \& IPC Technical Symposium; 1998; Bloomington, Minesota. USA; 1998. p. 263-278.

Cortés CA, Díaz PFJ, Ávila GE. Comportamiento productivo en gallinas de postura con la adición en la dieta de dos fuentes de metionina sintética. Veterinaria México 2001;32:183-187.

CVB. Verkorte tabel: Gegevens over chemische samenstelling, verteerbaarheid en voederwaarde van voedermiddelen). Lelystad: Centraal Veevoeder Bureau; 1996.

Dendy D, Dobraszczyk B. Cereales y productos derivados: química y tecnología. Zaragoza: Acribia; 2001.

Filho JJ, Vilar da Silva JH, Lindolfo da Silva E, Gomes Ribeiro ML, Dantas Martins TD, Boa-Viagem Rabello C. Methionine+Cystine requirements of semi-heavy laying hens from the starter to peak of egg production. Revista Brasileira de Zootecnia 2006;35(3):1063-1069.

Fuente Martinez B, Diaz Cruz A, Lecumberri Lopez J, Ávila González E. Digestible lysine and sulfur amino acids requirements in white leghorn hens. Veterinaria México 2005;36:135-145.

Garcia RG, Mendes AA, Almeida Paz ICL, Komiyama CM, Caldara FR, Nääs IA, Mariano WS. Implications of the use of sorghum in broiler production. Revista Brasileira de Ciência Avícola 2013;15(3):169-286.

Gomez S, Angeles ML. Effect of threonine and methionine levels in the diet of laying hens in the second cycle of production. Journal of Applied Poultry Research 2009;18:452-457.

Gómez RS, Angeles ML, Mariscal LG, Mejía GCA, Braña VD, Rentería FJA, et al. Estrategias para el uso eficiente de materias primas en porcicultura [libro técnico 1]. Querétaro: Centro Nacional de Investigación Disciplinaria en Fisiología y Mejoramiento Animal, INIFAP-SAGARPA; 2009.

Harms RH, Russel GB. Evaluation of the cystine requirement of the laying hen. Journal of Applied Poultry Research 1996;5:139-149.

Hy-Line Internacional Inc. W-36 Performance Standards Manual. Des Moines: Hy-Line International; 2011. p.1-20.

Jais $C$, Roth $F X$, Kirchgessner $M$. The determination of the optimum ratio between the essential amino acids in laying hen diets. Archiv für Geflügelkunde 1995;59:292-302.

Joly P. Re-evaluation of amino acids requirements for laying hens Part 1 : Methionine and cystine requirements. ISA Hendix Genetics 2010;1:114.

Lemme A. Amino acid recommendations for laying hens. Lohmann Information 2009;44:21-32.

Mariscal LG, Avila E, Tejada HI, Cuarón IJA, Vázquez PC. Tablas del contenido de aminoácidos totales y de los coeficientes de digestibilidad verdadera para aves y cerdos. México: INIFAP-Produce; 1998.

Mariscal-Landín G, Avellaneda JH, Reis de Souza TC, Aguilera A, Borbolla GA, Mar B. Effect of tannins in sorghum on amino acid ileal digestibility and on trypsin (E.C.2.4.21.4) and chymotrypsin (E.C.2.4.21.1) activity 
of growing pigs. Animal Feed Science and Technology 2004:117;245264.

Mariscal-Landín G, Reis de Souza TC, Avalos MA. Ileal amino acids digestibility of sorghum in weaned piglets and growing pigs. Animal Science 2010;4;1341-1348.

Narváez-Solarte W, Rostagno HS, Soares PR, Silva MA, Uribe Velasquez LF. Nutritional requirements in methionine+cystine for white-egg laying hens during the first cycle of production. International Journal of Poultry Science 2005;4:965-968.

Novak C, Yakout HM, Scheideler SE. The effect of dietary protein level and total sulfur amino acid:lysine ratio on egg production parameters and egg yield in Hy-Line W-98 hens. Poultry Science 2006;85:2195-2206.

NRC - National Research Council. Nutrient requirements of poultry. 9th ed. Washington: National Academic Press; 1994.

Polese C, Vianna N, Garcia C, Bartolomeu MA, Takahashi SE, Vilela VO, et al. Nutritional levels of digestible methionine + cystine to brown-egg laying hens from 50 to 66 weeks of age. Revista Brasileira de Zootecnia 2012;41(7):1691-1698.

Ramírez RE, Anaya EAM, Mariscal LG. Predicción de la composición química del grano de sorgo mediante espectroscopia de reflectancia en el infrarrojo cercano (NIRS). Técnica Pecuaria México 2005;43:1-11.

Rostagno HS, Albino LFT, Donzelle JL, Gomes PC, Oliveira RF, Lopes DC, et al. Brazilian tables for poultry and swine. composition of feedstuffs and nutritional requirements. 2nd ed. Vicosa: UFV; 2005. p.95-113.
Saki AA, Naseri Harsini R, Tabatabaei MM, Zamani P, Haghight M. Estimates of methionine and sulfur amino acid requirements for laying hens using different models. Revista Brasileira de Ciência Avícola 2012;14(3):159232.

SAS. SAS user's guide: statistics. Version 6. 4th ed. Cary: Statistical Analysis Systems Institute; 1990.

Selle PH, Cadogan DJ, Li X, Bryden WL. Implications of sorghum in broiler chicken nutrition. Animal Feed Science and Technology 2010;156:5774.

Shafer DJ, Carey JB, Prochaska JF, Sams AR. Effect of dietary methionine intake on egg component yield and composition. Poultry Science 1996;75:1080-1085.

Shafer DJ, Carey JB, Prochaska JF, Sams AR. Dietary methionine intake effects on egg component yield, composition, functionality, and texture profile analysis. Poultry Science 1998;77:1056-1062.

Steel RG, Torrie JH. Principles and procedures of statistics: a biometrical approach. 2nd ed. New York: McGraw-Hill; 1980.

Taylor JRN, Shewry PR. Editorial: Preface to sorghum and millet reviews. Journal of Cereal Science 2006;44:223.

Wong J, Lau T, Cai N, Singh J, Pedersen J, Vensel W, et al. Digestibility of protein and starch from sorghum (Sorghum bicolor) is linked to biochemical and structural features of grain endosperm. Journal of Cereal Science 2009;49:73-82. 